No 4069

Studia nad Autorytaryzmem i Totalitaryzmem 43, nr 2

Wrocław 2021

https://doi.org/10.19195/2300-7249.43.2.28

\author{
JANUSZ SAWICKI \\ ORCID: 0000-0002-2952-9544 \\ Uniwersytet Wrocławski \\ janusz.sawicki@uwr.edu.pl
}

\title{
Kara śmierci za przestępstwa dewizowe w totalitarnym systemie komunistycznej Polski Ludowej
}

\author{
Słowa kluczowe: Polska Ludowa, przestępczość dewizowa, kara śmierci, represje \\ stalinowskie, totalitaryzm.

\section{THE DEATH PENALTY FOR FOREIGN EXCHANGE CRIMES IN THE TOTALITARIAN SYSTEM OF THE COMMUNIST POLISH PEOPLE'S REPUBLIC}

\begin{abstract}
The subject of the article is the penalisation of foreign exchange crimes in the Act of October 28, 1950 on the prohibition of possessing foreign currencies, gold coins, gold, and platinum, as well as the tightening of penalties for certain foreign exchange offenses. In this act, illegal foreign exchange trading was threatened with the most severe penalties, including the death penalty. The article contains a historical outline of liability for foreign exchange crime, from the legal regulations in the Second Polish Republic to the Fiscal Penal Code in force. The author pays special attention to the Act of 1950, which is a symbol of criminal law during the period of Stalinist repressions in Polish People's Republic. The author introduces the atmosphere of those years, related to the currency reform and radical tightening of criminal liability for foreign exchange offenses, in particular for the illegal trade in foreign currencies. The article indicates the axiological foundations of applying penal repression in the economic area of the state, typical for the totalitarian system of the communist Polish People's Republic.
\end{abstract}

Keywords: Polish People's Republic, foreign exchange crime, the death penalty, Stalinist repressions, totalitarianism. 
Od początku Polski Ludowej siły komunistyczne, które przejęły władzę w Polsce, nie ukrywały, że prawo karne ma odegrać istotną rolę w realizacji celów politycznych i gospodarczych oraz w zachowaniu i umocnieniu podstaw nowego ustroju powojennego państwa. Dlatego spośród wielu ustaw i dekretów karnych bądź zawierających przepisy karne, wyjątkowe znaczenie miały te, które typizowały przestępstwa przeciwko państwu. Za szczególnie restrykcyjne w tym zakresie uznaje się: a) dekret Polskiego Komitetu Wyzwolenia Narodowego z dnia 23 września 1944 roku - Kodeks Karny Wojska Polskiego'; b) dekret z dnia 30 października 1944 roku o ochronie państwa ${ }^{2}$; c) dekret z dnia 16 listopada 1945 roku o przestępstwach szczególnie niebezpiecznych w okresie odbudowy państwa ${ }^{3}$; d) dekret z dnia 22 stycznia 1946 roku o odpowiedzialności za klęskę wrześniową i faszyzację życia państwowego ${ }^{4}$; e) dekret z dnia 13 czerwca 1946 roku o przestępstwach szczególnie niebezpiecznych w okresie odbudowy państwa ${ }^{5}$. Wymienione dekrety wpisują się $\mathrm{w}$ mroczny okres stalinizmu ${ }^{6} \mathrm{w}$ Polsce po II wojnie światowej, który w prawie karnym nazywany jest okresem represji stalinowskich. Wyjątkowo negatywną rolę odegrał w tym okresie wspomniany Kodeks Karny Wojska Polskiego, uchwalony jeszcze w czasie wojny, który uważany jest za początek ustawodawstwa Polski Ludowej w zakresie przestępstw przeciwko państwu ${ }^{7}$. Zawierał on rozdział obejmujący w art. 85-103 zbrodnie stanu, których popełnienie groziło karą śmierci. Przestępstwa te nazywane były kontrrewolucyjnymi ${ }^{8}$. W literaturze ocenia się, że wobec normatywnej treści tych przepisów i ich interpretacji trudno nawet mówić o jakimkolwiek nawiązującym do wartości fundamencie aksjologicznym tych przepisów - jedyną ich podstawą były interesy polityczne tych, którzy uzurpowali sobie w Polsce władzę i za wszelką cenę chcieli ją utrzymać, kosztem represji wobec stawiającego opór społeczeństwa ${ }^{9}$.

1 Dz.U. z 1944 r. Nr 6, poz. 27.

2 Dz.U. z 1944 r. Nr 10, poz. 50.

3 Dz.U. z 1945 r. Nr 53, poz. 300.

4 Dz.U. z 1946 r. Nr 5, poz. 46.

5 Dz.U. z 1946 r. Nr 30, poz. 192. Nosił taki sam tytuł, jak dekret z 16 listopada 1945 roku. Był powszechnie znany pod nazwą „małego kodeksu karnego” (m.k.k.).

6 Stalinizm to system rządów w ZSRR w latach dyktatury Józefa Stalina, a po II wojnie światowej (do około 1956 roku) także w krajach tak zwanej demokracji ludowej (w tym w Polsce). W polityce stalinizm oznaczał faktyczną władzę dyktatorską Stalina nad partią komunistyczną i państwem, rozrost aparatu bezpieczeństwa i ludobójstwa obejmujące eliminację wielu grup polityczno-społecznych, a nawet całych narodów. Jako system sprawowania władzy został oficjalnie potępiony na zjazdach KPZR w 1956 i 1961 roku (zob. Encyklopedia PWN w trzech tomach, t. 3, Warszawa 1999, s. 397).

7 A. Krukowski, [w:] System prawa karnego. O przestęsstwach w szczególności, red. I. Andrejew, L. Kubicki, t. 4, Warszawa 1985, s. 35.

${ }^{8}$ A. Lityński, Podstawy prawa terroru. O niektórych zmianach w prawie karnym pierwszej dekady Polski Ludowej, [w:] Z dziejów sądów i prawa, red. A. Lityński, Katowice 1992, s. 115.

${ }^{9}$ A. Grześkowiak, Aksjologiczne podstawy prawnokarnej ochrony Rzeczypospolitej Polskiej w perspektywie stuletnich dziejów, cz. 2, „Teka Komisji Prawniczej PAN Oddział w Lublinie” 13, 2020, nr 1, s. 133.

Studia nad Autorytaryzmem i Totalitaryzmem 43, nr 2, 2021

(C) for this edition by CNS 
Podstawowym organem stojącym na straży przepisów chroniących nowy porządek społeczno-polityczny był tworzony od lipca 1944 roku aparat bezpieczeństwa publicznego. W skład powołanego Polskiego Komitetu Wyzwolenia Narodowego ${ }^{10}$ wchodził Resort Bezpieczeństwa Publicznego z jednostkami terenowymi w postaci wojewódzkich, miejskich oraz powiatowych Urzędów Bezpieczeństwa Publicznego. Jego dominująca rola wynikała z adaptacji wzorców radzieckich, przyznających tej części aparatu państwowego rolę szczególną ${ }^{11}$. Aparat bezpieczeństwa publicznego w roli strażnika nowej rzeczywistości ustrojowej był organem niezmiernie efektywnym, działającym w sposób typowy dla systemów totalitarnych w ich komunistycznym wariancie. Andrzej Paczkowski dzieli pierwsze dziesięciolecie Polski Ludowej na dwa okresy: podbój państwa, czyli terror masowy (lata 1944-1947) oraz podbój społeczeństwa, czyli terror powszechny (lata 1948-1956) ${ }^{12}$. Z uwagi na przedmiot zainteresowania w niniejszym artykule, szczególne znaczenie ma ten drugi okres. W polityce represyjnej chodziło w nim nie tyle o zwalczanie środowisk konspiracyjnych (były już stosunkowo nieliczne i całkowicie rozproszone), ile o terror, który miał za zadanie zastraszenie społeczeństwa. Można śmiało stwierdzić, że jego celem był podbój społeczeństwa, uzyskanie całkowitego posłuszeństwa oraz wymuszenie lojalności wobec ideologii i uosabiającej ją partii komunistycznej. Był to przy tym terror powszechny, ukierunkowany na wroga wewnętrznego ${ }^{13}$.

Użyte w tytule niniejszego artykułu określenie „Polska Ludowa” stosowane było $\mathrm{w}$ ciągu sześciu lat poprzedzających uchwalenie konstytucji w 1952 roku $^{14}$ — obok nazwy oficjalnej państwa Rzeczpospolita Polska — choć w zasadzie tylko przez partię komunistyczną i jej sojuszników, mimo iż przymiotnik „ludowa” nie należał do stałego repertuaru pojęciowego ruchu komunistycznego. Tradycyjnie stosował je przede wszystkim ruch ludowy (chłopski). W literaturze historycznej uważa się, że określenie to było — podobnie jak wiele innych pojęć i nazw

10 PKWN został powołany jako tymczasowy organ władzy na ziemiach zajmowanych przez armię sowiecką. Składał się głównie z komunistów. Uznawał za nielegalne władze RP na uchodźstwie. Zwalczał Polskie Państwo Podziemne. Ogłosił manifest, zwany lipcowym, datowany na 22 lipca 1944 roku, w którym zawarto program reform społeczno-politycznych i określono sojusz z ZSRR. Wydał wiele dekretów, stanowiących podstawy terroru wobec opozycji politycznej. Przekształcony 31 grudnia 1944 roku w Rząd Tymczasowy (zob. A. Paczkowski, Od sfatszowanego zwycięstwa do prawdziwej klęski. Szkice do portretu PRL, Kraków 1999, s. 6; Encyklopedia $P W N$..., s. 3).

11 P. Majer, Przestępczość w Polsce w latach 1944-1956. Próba zestawień sumarycznych na podstawie materiałów własnych aparatu policyjnego, „Czasopismo Prawno-Historyczne” 71, 2019, z. 2, s. 77; szerzej zob. P. Kładoczny, Prawo jako narzędzie represji w Polsce Ludowej (1944-1956). Prawna analiza kategorii przestępstw przeciwko państwu, Warszawa 2004.

12 A. Paczkowski, Polacy pod obca i własna przemoca, [w:] S. Courtois et al., Czarna księga komunizmu. Zbrodnie, terror, prześladowania (wstęp do wydania polskiego K. Kersten), Warszawa 1999, s. 351-365.

13 A. Paczkowski, Od sfatszowanego..., s. 55-56.

14 Konstytucja Polskiej Rzeczypospolitej Ludowej uchwalona w dniu 22 lipca 1952 roku (Dz.U. z 1952 r. Nr 33, poz. 232).

Studia nad Autorytaryzmem i Totalitaryzmem 43, nr 2, 2021

(C) for this edition by CNS 
— zawłaszczone przez komunistów dla łatwiejszego zdobycia legitymizacji. Nazwa Polska Rzeczpospolita Ludowa - formalnie rzecz biorąc - obowiązywała właściwie dopiero od 22 lipca 1952 i aż do 29 grudnia 1989 roku, kiedy kolejna nowelizacja konstytucji przywróciła dawną nazwę Rzeczpospolita Polska. Przyjęło się wszakże określeniem „PRL” obejmować także okres od połowy 1944 roku, ściślej od ogłoszenia 22 lipca przez radio moskiewskie faktu utworzenia Polskiego Komitetu Wyzwolenia Narodowego ${ }^{15}$.

Niniejszy artykuł ma na celu ukazać praktyczny wymiar systemu totalitarnego obowiązującego w komunistycznej Polsce Ludowej początku lat pięćdziesiątych XX wieku w obszarze kryminalizacji i penalizacji czynów godzących w przepisy dewizowe, oparty na naczelnym założeniu, że podstawowym instrumentem zwalczania przestępczości dewizowej ma być zastraszenie potencjalnych sprawców, a w szerszym kontekście całego społeczeństwa, a także eliminacja tych, którzy zastraszyć się nie dali i podjęli działalność przestępczą. Warto też porównać ówczesny model odpowiedzialności karnej skarbowej z obecnym modelem tej odpowiedzialności, opartym na zupełnie odmiennej aksjologii.

Pierwsza polska ustawa karna skarbowa, uchwalona 2 sierpnia 1926 roku $^{16}$ z mocą obowiązującą od 1 stycznia 1927 roku, będąca zarazem pierwszym całościowo opracowanym aktem prawnym w dziele porządkowania prawa karnego po okresie zaborów, nie obejmowała czynów karalnych związanych z prawem dewizowym. Także kolejne akty prawne regulujące prawo karne skarbowe w II Rzeczypospolitej, to jest ustawa karna skarbowa z dnia 18 marca 1932 roku $^{17}$ oraz dekret Prezydenta Rzeczypospolitej z dnia 3 listopada 1936 roku - Prawo karne skarbowe ${ }^{18}$, nie penalizowały dewizowych czynów zabronionych. Czyny karalne w zakresie naruszeń przepisów dewizowych były początkowo uregulowane odrębnymi aktami prawnymi, niewchodzącymi w skład prawa karnego skarbowego. Już 9 lipca 1920 roku uchwalono ustawę w przedmiocie udzielenia rządowi pełnomocnictw do wydawania rozporządzeń w sprawie regulowania obrotu pieniężnego z krajami zagranicznymi ${ }^{19}$. Akt ten zawierał również przepis dotyczący sankcji karnych za przekroczenia postanowień, które miały być zawarte w przyszłych rozporządzeniach wykonawczych. Ustawa z 1920 roku obowiązywała do 1927, kiedy to została uchylona rozporządzeniem ministra skarbu z dnia 2 listopada 1927 roku w porozumieniu z ministrem sprawiedliwości w sprawie zniesienia ograniczeń obrotu dewizami i walutami zagranicznymi oraz obrotu pieniężnego z zagranicą ${ }^{20}$. Nową reglamentację dewizową wydano dopiero dekretem Prezydenta Rzeczypospolitej z dnia 26 kwietnia 1936 roku w sprawie obrotu

\footnotetext{
15 A. Paczkowski, Od sfatszowanego..., s. 6.

16 Dz.U.R.P. z 1926 r. Nr 105, poz. 609.

17 Dz.U.R.P. z 1932 r. Nr 34, poz. 335.

18 Dz.U.R.P. z 1936 r. Nr 84, poz. 581.

19 Dz.U.R.P. z 1920 r. Nr 56, poz. 347.

20 Dz.U.R.P. z 1927 r. Nr 97, poz. 858.
} 
zagranicznymi i krajowymi środkami płatniczymi ${ }^{21}$. W okresie międzywojennym dekret ten był wielokrotnie nowelizowany. Ostatnia nowela przeprowadzona dekretem Prezydenta Rzeczypospolitej z dnia 2 września 1939 roku o zmianie dekretu Prezydenta Rzeczypospolitej w sprawie obrotu pieniężnego z zagranicą oraz obrotu zagranicznymi i krajowymi środkami płatniczymi ${ }^{22}$ wprowadziła obowiązek zgłoszenia i zaofiarowania do skupu posiadanych w kraju zagranicznych środków płatniczych, złota i papierów wartościowych oraz poważnie zaostrzyła zagrożenie karne za przestępstwa dewizowe ${ }^{23}$. W praktyce chodziło o dostosowanie sytuacji ekonomicznej do potrzeb wojny, toteż za uczynienie sobie przez sprawcę procederu z popełniania przestępstw dewizowych groziła kara nie niższa niż pięć lat więzienia i 200 tysięcy złotych grzywny, jak również przepadek przedmiotów przestępstwa. Sąd mógł wymierzyć karę więzienia dożywotnio, a grzywnę do wysokości nieograniczonej. Dekret przewidywał, że minister finansów ogłosi jednolity tekst dekretu Prezydenta RP z dnia 26 kwietnia 1936 roku z uwzględnieniem zmian wprowadzonych przez dekret z dnia 2 września 1939 roku. Oczywiście nigdy nie było możliwości jego wykonania ${ }^{24}$.

Spośród wszystkich działów prawa karnego w Polsce Ludowej prawo karne skarbowe - poza prawem karnym wojskowym - zostało zreformowane najwcześniej. Dostosowanie ustawodawstwa karnego skarbowego do warunków cząstkowego etapu budownictwa socjalistycznego zostało przeprowadzone w 1947 roku dekretem z dnia 11 kwietnia - Prawo karne skarbowe ${ }^{25}$, z moca obowiązującą od dnia 1 czerwca 1947 roku. Dekret ten został uzupełniony rozporządzeniem ministrów skarbu, sprawiedliwości, administracji publicznej, Ziem Odzyskanych, obrony narodowej i bezpieczeństwa publicznego z dnia 14 sierpnia 1948 roku - Przepisy wykonawcze do prawa karnego skarbowego ${ }^{26}$. Dekret ten przewidywał po raz pierwszy unifikację przepisów dotyczących przestępstw podatkowych oraz przestępstw z zakresu opłat skarbowych w ramach prawa karnego skarbowego, natomiast przepisy dotyczące przestępstw dewizowych nadal pozostawały poza formalnym prawem karnym skarbowym. Przedwojenny system reglamentacji dewizowej (dekret z dnia 26 kwietnia 1936 roku) obowiązywał po II wojnie światowej z niezbędnymi zmianami strukturalnymi aż do roku 1952. Reglamentacja dewizowa miała w początkowym okresie bardzo poważne znaczenie nie tylko ekonomiczne (utrzymanie wartości pieniądza polskiego, walka z rosnącą spekulacją), ale także polityczno-społeczne (okres ostrej walki

21 Dz.U.R.P. z 1936 r. Nr 32, poz. 249.

22 Dz.U.R.P. z 1939 r. Nr 87, poz. 549.

23 Z. Siwik, Systematyczny komentarz do ustawy karnej skarbowej. Część ogólna, Wrocław 1993, s. 2-4.

24 W.E. Łyszczak, Wojenne Dzienniki Ustaw sierpień-wrzesień 1939 r., „Palestra” 38, 1994, nr 11, s. 127.

25 Dz.U. z 1947 r. Nr 32, poz. 140.

26 Dz.U. z 1948 r. Nr 42, poz. 307. 
klasowej z przeżytkami kapitalizmu oraz między różnymi ustrojami politycznymi $)^{27}$. W początkowym okresie sprowadzała się $\mathrm{w}$ zasadzie do nakazu stawiania do dyspozycji państwa części lub całości uzyskanych za granicą z handlu lub ze zdobyczy wojennej wartości w postaci pieniądza kruszcowego, a następnie monetarnego, jak również dewiz, oraz do zakazu wywozu do innego kraju w jakiejkolwiek formie - wartości majątkowych. $Z$ biegiem czasu ta ingerencja władz przybrała określone formy zakazów i nakazów związanych z reglamentacją obrotu dewizowego ${ }^{28}$.

Istotne przeobrażenia prawa dewizowego zostały zapoczątkowane w 1950 ro$\mathrm{ku} \mathrm{w}$ ramach podjętej reformy walutowej. Była to już druga reforma walutowa w Polsce Ludowej, dokonana 30 października 1950 roku (pierwszej wymiany pieniędzy dokonano dekretem PKWN w 1944 roku). Wymianę pieniędzy władze przygotowywały w ścisłej tajemnicy i z dużym wyprzedzeniem ${ }^{29}$. Ogłoszono ją 28 października 1950 roku w oparciu o ustawę z dnia 28 października 1950 roku o zmianie systemu pieniężnego ${ }^{30}$, a nowy złoty wchodził do obiegu dwa dni później, natomiast już 8 listopada 1950 roku traciły ważność wszystkie pieniądze będące w obiegu przed dniem 30 października. W piśmiennictwie zwraca się uwagę na to, że wymiana pieniędzy przeprowadzona w 1950 roku była powiązana $\mathrm{z}$ denominacją złotego. Pieniądze zdeponowane w bankach wymieniano w proporcjach $100 \mathrm{zl}$ starych na 3 zł nowe (tak samo przeliczono wszystkie ceny i płace pracownicze). Natomiast gotówkę wymieniano w stosunku $100 \mathrm{zł}$ starych na 1 zł nowy, nadto w ograniczonym zakresie. Ta trzykrotna dysproporcja uderzała w tych, którzy trzymali gotówkę w domu lub obracali gotówką poza obiegiem bankowym. Władze komunistyczne uzasadniały reformę koniecznością zwalczania prywaciarzy i spekulantów ${ }^{31}$.

W tych szczególnych okolicznościach uchwalona została w dniu 28 października 1950 roku także ustawa o zakazie posiadania walut obcych, monet złotych, złota i platyny oraz zaostrzeniu kar za niektóre przestępstwa dewizowe ${ }^{32}$, która weszła w życie z dniem 30 października 1950 roku. Przewidywała ona surowe kary więzienia (od 2 do 10 lat) aż do kary dożywotniego więzienia włącznie. Nadto w art. 9 ust. 1 za obrót wszelkiego rodzaju walutą obcą, monetami złotymi, złotem i platyną bez zezwolenia Komisji Dewizowej — obok wymienionych kar - przewidywała karę śmierci. W myśl ust. $2 \mathrm{w}$ przypadku skazania za takie przestępstwo sąd obligatoryjnie orzekał grzywnę w sumie do 300 tysięcy zł

27 Z. Siwik, op. cit., s. 4-5.

${ }^{28}$ L. Wilk, [w:] L. Wilk, J. Zagrodnik, Kodeks karny skarbowy. Komentarz, Warszawa 2021, s. $500-501$.

29 Nowe banknoty wydrukowano w Szwecji, Czechosłowacji i na Węgrzech z datą 1 lipca 1948 roku. Były przechowywane w tajemnicy w strzeżonych magazynach wojskowych (J. Kaliński, Z. Landau, Gospodarka Polski Ludowej 1944-1955, Warszawa 1986, s. 240).

30 Dz.U. z 1950 r. Nr 50, poz. 459.

31 J. Kaliński, Z. Landau, op. cit., s. 240 n.

32 Dz.U. z 1950 r. Nr 50, poz. 460. 
i przepadek walut obcych, monet złotych, złota i platyny, stanowiących przedmiot przestępstwa. Na podstawie tego przepisu mógł także orzec przepadek całego majątku. Według art. 10 tej ustawy sprawy o przestępstwa spenalizowane w art. 9 podlegały postępowaniu doraźnemu. W ocenie Zygfryda Siwika mimo przejściowego charakteru ustawa ta miała szczególny akcent klasowo-polityczny ${ }^{33}$. Choć przestała obowiązywać z dniem 5 czerwca 1952 roku na mocy art. 39 pkt 3 ustawy dewizowej z dnia 28 marca 1952 roku $^{34}$, a więc obowiązywała niecałe dwa lata, odcisnęła się wyjątkowym piętnem w polskim prawie karnym. Stanowiła ona szczególne urzeczywistnienie represji stalinowskich, gdyż przewidywała najsurowszą karę połączoną z przepadkiem całego majątku za przestępstwo dewizowe, którego waga w żadnym przypadku nie może dorównywać najcięższym zbrodniom, za które prawo karne przewidywało karę śmierci. Trzeba też zauważyć, że tej najsurowszej kary za przestępczość dewizową nie przewidywał nawet dekret z dnia 2 września 1939 roku wprowadzony na czas wojny.

Kara śmierci groziła w art. 9 ust. 1 przedmiotowej ustawy między innymi za nielegalny obrót walutą obcą. W literaturze historycznej odnoszącej się do obrotu dewizowego w Polsce podkreśla się, że zjawisko nielegalnego handlu walutami pojawiło się już podczas okupacji niemieckiej w czasie II wojny światowej. Zjawisko to rozwijało się także w Polsce Ludowej, z powodu monopolu państwa w zakresie dewizowym i znacznej rozbieżności między oficjalnym kursem walut w gospodarce centralnie planowanej a dużo wyższym kursem czarnorynkowym. W tych warunkach cudzoziemcy chętnie wymieniali swoją walutę na złotówki u tak zwanych „,waluciarzy”, którzy oferowali wyższy kurs wymiany niż państwowe banki. Świadczyli oni swoje usługi przed hotelami, bankami, dworcami i lotniskami oraz na giełdach samochodowych, a z czasem przed sklepami sieci Baltona i Pewex, gdzie można było kupić towary wyłącznie za walutę obcą lub bony PKO. Pod koniec lat pięćdziesiątych XX wieku określenie „waluciarz” zostało zastąpione nowym: „cinkciarz”. Jak podają językoznawcy, pochodzi ono od zniekształconego angielskiego change money ${ }^{35}$. Wymiana pieniędzy u waluciarzy, a potem cinkciarzy, związana była z dużym ryzykiem, z uwagi na dość częste oszustwa polegające na podmianie pieniędzy na papier na końcu transakcji, jak też używaniu banknotów fałszywych lub nawet wycofanych z obiegu. Legalną alternatywę dla działalności cinkciarzy stworzyła dopiero ustawa z dnia 15 lutego 1989 ro$\mathrm{ku}$ - Prawo dewizowe ${ }^{36}$, która zniosła monopol państwa w dziedzinie skupu i sprzedaży walut obcych (wcześniej działalność w tej dziedzinie była zastrzeżona wyłącznie dla banków dewizowych lub uprawnionych podmiotów, na

33 Z. Siwik, op. cit., s. 5.

34 Dz.U. z 1952 r. Nr 21, poz. 133. Była to ustawa o charakterze administracyjnym, w odróżnieniu od ustawy karnej dewizowej z tej samej daty (Dz.U. z 1952 r. Nr 21, poz. 134).

35 A. Markowski, R. Pawelec, Wielki słownik wyrazów obcych i trudnych, Warszawa 2001, s. 114.

36 Dz.U. z 1989 r. Nr 6, poz. 33 ze zm. 
przykład biur podróży czy oddziałów Polskiego Związku Motorowego). Ustawa ta umożliwiła prowadzenie przez krajowe osoby fizyczne punktów kupna-sprzedaży walut i pośrednictwa w zakupie walut obcych, zwanych kantorami wymiany walut. W praktyce doprowadziło to do zniknięcia z rynku walutowego cinkciarzy. Niektórzy z nich, dysponując większą gotówką, od razu otworzyli kantory, a nawet całe sieci kantorów wymiany walut i w ten sposób stali się legalnymi przedsiębiorcami, „legalizującymi” w ten sposób kapitał zgromadzony przez lata nielegalnej działalności ${ }^{37}$.

Zagrożenie od 1950 roku nielegalnego obrotu walutą obcą karą śmierci nie mieści się w dzisiejszej aksjologii. Poszukując podstaw aksjologicznych komunistycznego ustawodawstwa Polski Ludowej mającego za cel ochronę państwa, należy wyraźnie stwierdzić, że bezpośredni wpływ na treść przepisów chroniących Polskę Ludową nie miały określone wartości, ale przede wszystkim ideologia przekazywana przez polityczne gremia rządzące, odwołująca się do klasyków marksizmu-leninizmu ${ }^{38} \mathrm{i}$ doświadczeń sowieckich $\mathrm{w}$ dziedzinie zwalczania przestępczości ${ }^{39}$. Zadaniem ówczesnego prawa karnego była ochrona komunistycznego państwa, uosobionego zwłaszcza w jego władzach partyjno-rządowych, złamanie oporu klas wrogich socjalistycznemu państwu oraz zniszczenie wszelkiej opozycji politycznej i zabezpieczenie interesów rządzących, pod ogólnym szyldem ochrony mas pracujących miast i wsi. Na tle takiej racjonalizacji wprowadzanych przepisów prawnokarnych chroniących Polskę Ludową, trudno nawet mówić o ich stabilnej podstawie aksjologicznej, gdyż dostarczały jej stale aktualizowane rezultaty walki z narodem polskim, niegodzącym się z ustrojem narzuconym przemocą i terrorem, także terrorem prawa karnego. Podstawy aksjologiczne ustawodawstwa mającego na celu ochronę Polski Ludowej nie miały zatem żadnego odniesienia do wartości konstytucyjnych. Tworzone komunistyczne prawo karne było przede wszystkim prawem interesu panującej klasy ${ }^{40}$. Dzięki niemu komuniści mogli sprawować władzę i kontrolować społeczeństwo w sposób charakterystyczny dla totalitaryzmu ${ }^{41}$, powszechnie uważanego za skrajną i specyficzną postać rządów autorytarnych.

37 W. Wójtowicz, Prawo dewizowe z komentarzem, Warszawa 1992, s. 39 n.; M. Przybylik, To byto tak. Dzień Targowy, Warszawa 2009, s. 303-304; zob. też J. Sawicki, Wadliwe prowadzenie kantoru jako przestępstwo lub wykroczenie skarbowe, „Prokuratura i Prawo” 2009, nr 3, s. 41-59.

38 L. Lernell, Materiały do nauki prawa karnego. Nauka o przestępczości i karze, Łódź-Warszawa 1955, s. 24.

${ }^{39}$ A. Grześkowiak, op. cit., s. 137.

40 Ibidem, s. 136-137.

41 Totalitaryzm oznacza system rządów (oraz wspierającą go ideologię) charakterystyczny dla państw w XX wieku. Stanowi nowoczesną odmianę tyranii i despotyzmu, zapewniającą rządzącym o wiele skuteczniejszą kontrolę nad społeczeństwem. W komunizmie sowieckim i krajów znajdujących się w sowieckiej strefie wpływów (również w Polsce) występował pod hasłami nacjonalizacji własności i walki klasowej, opierając się na cenzurze i propagandzie oraz całkowitym podporządkowaniu społeczeństwa partii komunistycznej. Od tradycyjnych rządów autokratycznych 
W nauce prawa karnego zwraca się uwagę na wyjątkowy charakter kary śmierci. Witold Świda wskazywał, że dla zwolenników sprawiedliwego odwetu jest ona odpowiednią odpłatą za zabójstwo (śmierć za śmierć). Ze stanowiska prewencji ogólnej kara śmierci, najsurowsza ze wszystkich kar, przedstawia się jako środek najlepiej powstrzymujący zastraszeniem przed popełnianiem przestępstw zagrożonych tą karą, gdyż życie jest dobrem, które człowiek ceni najwyżej. Z kolei opowiadający się za prewencją szczególną widzą w niej niezawodny sposób unieszkodliwienia przestępcy, którego nie da się już ani poprawić, ani zastraszyć. Świda zwracał jednocześnie uwagę, że kara śmierci obraża uczucia humanitarne człowieka, a największą jej wadą jest jej nieodwracalność w przypadku wydania błędnego wyroku. Jeżeli wyrok taki zostanie wykonany, nie da się już tego naprawić 42 .

Niezależnie od powyższych poglądów, nie ulega wątpliwości, że zagrożenie karą śmierci przestępstw o charakterze finansowym jest nieadekwatne do ich społecznej szkodliwości. W doktrynie wskazuje się, że kary śmierci nie da się dzisiaj pogodzić z zasadą godności człowieka i współczesnym systemem wartości, nawet $\mathrm{w}$ przypadku najcięższych zbrodni, a tym bardziej w odniesieniu do przestępstw gospodarczych. Funkcję zabezpieczenia społeczeństwa przed najgroźniejszymi przestępcami wystarczająco realizuje kara dożywotniego pozbawienia wolności ${ }^{43}$. Karę śmierci w polskim prawie karnym zniósł ostatecznie Kodeks karny z 1997 roku $^{44}$. Wcześniej ustawą nowelizacyjną z dnia 12 lipca 1995 roku ${ }^{45}$ wprowadzono zakaz jej wykonywania przez pięć lat od wejścia $\mathrm{w}$ życie tej ustawy (było to formalne moratorium). Rezygnacja $\mathrm{z}$ kary śmierci w Polsce została formalnie zatwierdzona dnia 14 kwietnia 2000 roku ustawową ratyfikacją Protokołu nr 6 do Konwencji o ochronie praw człowieka i podstawowych wolności, dotyczącą zniesienia kary śmierci ${ }^{46}$.

Trzeba jednak dodać, że kara śmierci była szeroko stosowana zarówno w Polsce Ludowej, jak i w całym okresie PRL. Zwłaszcza w latach pięćdziesiątych i sześćdziesiątych XX wieku dochodziło do licznych procesów karnych dotyczących także przestępstw gospodarczych (najgłośniejsze $\mathrm{z}$ nich to tak zwane afery mięsna, skórzana, węglowa, ceglana czy zegarkowa, o charakterze

różni go przede wszystkim ideologiczna nadbudowa oraz skala zinstytucjonalizowanego terroru (Encyklopedia PWN..., s. 601).

42 W. Świda, Prawo karne, Warszawa 1989, s. 240-241.

43 J. Kosonoga-Zygmunt, [w:] Kodeks karny. Komentarz, red. R.A. Stefański, Warszawa 2018, s. 303.

44 Ustawa z dnia 6 czerwca 1997 roku — Kodeks karny (Dz.U. z 2020 r. poz. 1444 ze zm.); obowiązuje od 1 września 1998 roku.

45 Ustawa z dnia 12 lipca 1995 roku o zmianie kodeksu karnego, kodeksu karnego wykonawczego oraz o podwyższeniu dolnych i górnych granic grzywien i nawiązek w prawie karnym (Dz.U. z 1995 r. Nr 95, poz. 475).

46 Ustawa z dnia 14 kwietnia 2000 roku o ratyfikacji Protokołu nr 6 do Konwencji o ochronie praw człowieka i podstawowych wolności, dotyczącego zniesienia kary śmierci (Dz.U. z 2000 r. Nr 48, poz. 549). 
dewizowo-przemytniczym), których swoistym symbolem był proces pokazowy w największej aferze czasów gomułkowskich, tak zwanej aferze mięsnej (w latach 1964-1965), zakończony orzeczeniem kary śmierci wobec Stanisława Wawrzeckiego (dyrektora Miejskiego Handlu Mięsem Warszawa-Praga) i jej wykonaniem 19 marca 1965 roku (27 lipca 2004 roku Sąd Najwyższy uchylił wyroki w aferze mięsnej, uzasadniając, że zapadły one z rażącym naruszeniem prawa ${ }^{47}$. W kodeksie karnym z 1969 roku, wzorowanym na radzieckim ustawodawstwie karnym, karą śmierci zagrożonych było dziewięć najpoważniejszych przestępstw, a kara ta występowała także w niektórych ustawach szczególnych. Rażącym odstępstwem od wyjątkowego charakteru kary śmierci był dekret z dnia 12 grudnia 1981 roku o postępowaniach szczególnych w sprawach o przestępstwa i wykroczenia w czasie obowiązywania stanu wojennego ${ }^{48}$, wprowadzonego przez władze komunistyczne PRL 13 grudnia 1981 roku, który za przestępstwo podlegające postępowaniu doraźnemu rozszerzył możliwość stosowania kary śmierci aż do 86 przestępstw ${ }^{49}$. Ostatnia kara śmierci została wykonana w PRL 21 kwietnia 1988 roku w Krakowie ${ }^{50}$, a ostatni wyrok śmierci, już w III Rzeczypospolitej, został orzeczony przez Sąd Wojewódzki w Elblągu 7 lutego 1996 roku $^{51}$.

Wracając do karalności przestępczości dewizowej po uchyleniu ustawy z dnia 28 października 1950 roku, to została ona uregulowana ustawą karną dewizową z dnia 28 marca 1952 roku $^{52}$. Było to pierwsze w historii polskiego ustawodawstwa dewizowego rozdzielenie przepisów administracyjnych od karnych dewizowych. Ustawa karna dewizowa z 1952 roku była typową ustawą dodatkową, ale powszechnego prawa karnego, a nie prawa karnego skarbowego. Zawierała ona katalog przestępstw dewizowych z bardzo surowymi sankcjami ${ }^{53}$ (z karą dożywotniego pozbawienia wolności włącznie), ale już bez kary śmierci. Włączenie przestępstw i wykroczeń dewizowych do prawa karnego skarbowego, które nastąpiło w ustawie karnej skarbowej z dnia 13 kwietnia 1960 roku $^{54}$, wiązało się z uchyleniem ustawy karnej dewizowej z 1952 roku i radykalnym złagodzeniem odpowiedzialności karnej za przestępstwa dewizowe (groziła za nie głównie

${ }^{47}$ M. Romański, Afery i nadużycia gospodarcze. Przyczynek do badań nad przestępczościa w PRL, „Studia z Historii Społeczno-Gospodarczej” 12, 2013, s. 123-135.

48 Dz.U. z 1981 r. Nr 29, poz. 156 ze zm.

49 Z. Sienkiewicz, [w:] Prawo karne materialne. Część ogólna i szczególna, red. M. Bojarski J. Giezek, Z. Sienkiewicz, Warszawa 2020, s. 354.

${ }^{50}$ W zakładzie karnym przy ul. Montelupich w Krakowie na skazanym 12 czerwca 1986 roku przez Sąd Wojewódzki w Tarnowie za gwałt i zabójstwo kobiety oraz usiłowanie zabójstwa jej córek, Lista osób skazanych na karę śmierci w Polsce po roku 1945, https://pl.wikipedia.org/wiki/Lista_os\%C3\%B3b_skazanych_na_kar\%C4\%99_\%C5\%9Bmierci_w_Polsce_po_roku_1945 (dostęp: 7.12.2021).

51 Za zabójstwo dwóch kobiet (Lista osób skazanych...).

52 Dz.U. z 1952 r. Nr 21, poz. 134.

53 Z. Siwik, op. cit., s. 5.

54 Dz.U. z 1960 r. Nr 21, poz. 123 ze zm. 
grzywna, a za niektóre kara aresztu do trzech lat). Był to rezultat dostosowania sankcji za przestępstwa dewizowe do odmiennego systemu penalnego prawa karnego skarbowego. Dość szybko okazało się, że sankcje za przestępstwa dewizowe typu aferowego, spekulanckiego i przemytniczego były zbyt łagodne. Dlatego ustawą z dnia 29 czerwca 1963 roku o zmianie ustawy karnej skarbowej ${ }^{55}$ wprowadzono do ustawy karnej skarbowej z 1960 roku nieznaną w niej karę więzienia, zaostrzając poważnie sankcje karne za przestępstwa dewizowe (aż do kary więzienia na czas nie krótszy od dwóch lat do lat 15$)^{56}$. W kolejnej ustawie karnej skarbowej z dnia 26 października 1971 roku niektóre przestępstwa dewizowe zagrożone były karą w postaci pozbawienia wolności do lat pięciu, a w przypadku recydywy od roku do lat dziesięciu.

Pod rządami ustaw karnych skarbowych z 1960 i 1971 roku czyny zabronione naruszające prawo dewizowe stanowiły zasadniczą grupę przestępstw i wykroczeń skarbowych. Świadczyło o tym umiejscowienie tych przepisów, gdyż były one uregulowane w pierwszym rozdziale części szczególnej obu ustaw. Taka waga przestępstw i wykroczeń dewizowych związana była $\mathrm{z}$ daleko posuniętą reglamentacją obrotu dewizowego. Uwarunkowania powyższe były tak silne, że przez lata wiele osób kojarzyło prawo karne skarbowe przede wszystkim z przestępczością dewizową ${ }^{57}$. Obowiązujący kodeks karny skarbowy z 1999 roku $^{58}$ za przestępstwa dewizowe przewiduje przede wszystkim karę grzywny w systemie stawek dziennych, a tylko za dwa przestępstwa także karę pozbawienia wolności od pięciu dni do dwóch lat ${ }^{59}$. W przypadku nadzwyczajnego obostrzenia kara ta wynosi od jednego miesiąca do trzech lat ${ }^{60}$. W obecnym prawie karnym skarbowym dominuje model karania oparty na ustawowym priorytecie środków dolegliwości ekonomicznej, z dominacją kary grzywny i majątkowych środków karnych (głównie przepadku przedmiotów) ${ }^{61}$. Należy też zaznaczyć, że kolejność rozdziałów części szczególnej kodeksu karnego skarbowego opiera się na hierarchii dóbr przyjętej w 1999 roku. Najważniejszą, bo uregulowaną jako pierwsza i zarazem najliczniejszą grupę czynów zabronionych stanowią przestępstwa i wykroczenia podatkowe. Przestępstwa i wykroczenia dewizowe zajmują w tej hierarchii dopiero trzecie miejsce.

55 Dz.U. z 1963 r. Nr 28, poz. 167.

56 Z. Siwik, op. cit., s. 6.

57 A. Bartosiewicz, R. Kubacki, Kodeks karny skarbowy. Przestęstwa i wykroczenia podatkowe oraz dewizowe, Warszawa 2010, s. 560.

58 Ustawa z dnia 10 września 1999 roku — Kodeks karny skarbowy (Dz.U. z 2021 r. poz. 408 ze zm.).

59 Za przestępstwo wyłudzenia zezwolenia dewizowego z art. 97 § 1 k.k.s. oraz za przestępstwo użycia takiego zezwolenia $\mathrm{z}$ art. 97 § 2 k.k.s.

60 Na podstawie art. 38 § 1 pkt 3 k.k.s.

61 Zob. J. Sawicki, Charakterystyka sankcji w prawie karnym skarbowym, [w:] Współczesne przekształcenia sankcji karnych — zagadnienia teorii, wyktadni i praktyki stosowania, red. P. Góralski, A. Muszyńska, Warszawa 2018, s. 297-313. 
Podsumowując, należy stwierdzić, że obrót dewizowy będący podstawową konstrukcją prawną ustawodawstwa dewizowego, różnorodnie ujmowany i określany w ustawach dewizowych zarówno okresu międzywojennego, jak i w Polsce powojennej, podlegał różnym ograniczeniom, rzutującym na zachowania w sferze gospodarczo-finansowej. Zakres i stopień szczegółowości tych przepisów był zawsze funkcją przyjętej przez ustawodawcę w danym okresie polityki ${ }^{62}$. W ustawodawstwie karnym okresu Polski Ludowej penalizacja przestępstw i wykroczeń dewizowych odgrywała szczególnie ważną rolę, a rozwijała się w sposób typowy dla systemu totalitarnego. W piśmiennictwie prawa karnego skarbowego ${ }^{63}$ podkreśla się, że apogeum restrykcyjne reglamentacji dewizowej osiągnięte zostało na początku lat pięćdziesiątych ubiegłego stulecia poprzez zagrożenie ukarania posiadania walut obcych karą więzienia, a obrotu nimi także karą śmierci, co słusznie uznawane jest za ponury rozdział historii polskiego ustawodawstwa karnego w obszarze przestępczości finansowej. W odniesieniu do tych przepisów trudno mówić o jakimkolwiek fundamencie aksjologicznym. Z ulgą zatem można odnotować, że ten stan rzeczy należy już od dawna do przeszłości, a obowiązujące regulacje prawa karnego skarbowego są wyrazem poszanowania podstawowych wartości, zasad humanitaryzmu, standardów konstytucyjnych i prawa międzynarodowego.

\section{Bibliografia}

Bartosiewicz A., Kubacki R., Kodeks karny skarbowy. Przestępstwa $i$ wykroczenia podatkowe oraz dewizowe, Warszawa 2010.

Encyklopedia PWN w trzech tomach, t. 3, Warszawa 1999.

Grześkowiak A., Aksjologiczne podstawy prawnokarnej ochrony Rzeczypospolitej Polskiej w perspektywie stuletnich dziejów, cz. 2, „Teka Komisji Prawniczej PAN Oddział w Lublinie” 13, 2020, nr 1.

Jerzak S., Procesy ewolucyjne polskiego ustawodawstwa dewizowego, „Przegląd Ustawodawstwa Gospodarczego" 2002, nr 1.

Kaliński J., Landau Z., Gospodarka Polski Ludowej 1944-1955, Warszawa 1986.

Kładoczny P., Prawo jako narzędzie represji w Polsce Ludowej (1944-1956). Prawna analiza kategorii przestęstw przeciwko państwu, Warszawa 2004.

Kosonoga-Zygmunt J., [w:] Kodeks karny. Komentarz, red. R.A. Stefański, Warszawa 2018.

Krukowski A., System prawa karnego. O przestępstwach w szczególności, red. I. Andrejew, L. Kubicki, t. 4, Warszawa 1985.

Lernell L., Materiały do nauki prawa karnego. Nauka o przestępczości i karze, Łódź Warszawa 1955.

Lista osób skazanych na kare śmierci w Polsce po roku 1945, https://pl.wikipedia.org/wiki/Lista_ os\%C3\%B3b_skazanych_na_kar\%C4\%99_\%C5\%9Bmierci_w_Polsce_po_roku_1945.

62 S. Jerzak, Procesy ewolucyjne polskiego ustawodawstwa dewizowego, „Przegląd Ustawodawstwa Gospodarczego" 2002, nr 1, s. 9.

63 L. Wilk, [w:] L. Wilk, J. Zagrodnik, op. cit., s. 501-502. 
Lityński A., Podstawy prawa terroru. O niektórych zmianach w prawie karnym pierwszej dekady Polski Ludowej, [w:] Z dziejów sądów i prawa, red. A. Lityński, Katowice 1992.

Łyszczak W.E., Wojenne Dzienniki Ustaw sierpień-wrzesień 1939 r., „Palestra” 38, 1994, nr 11.

Majer P., Przestępczość w Polsce w latach 1944-1956. Próba zestawień sumarycznych na podstawie materiałów własnych aparatu policyjnego, „Czasopismo Prawno-Historyczne” 71, 2019, z. 2.

Markowski A., Pawelec R., Wielki słownik wyrazów obcych i trudnych, Warszawa 2001.

Paczkowski A., Polacy pod obca i własna przemoca, [w:] S. Courtois et al., Czarna księga komunizmu. Zbrodnie, terror, prześladowania (wstęp do wydania polskiego K. Kersten), Warszawa 1999.

Paczkowski A., Od sfatszowanego zwycięstwa do prawdziwej klęski. Szkice do portretu PRL, Kraków 1999.

Przybylik M., To byto tak. Dzień Targowy, Warszawa 2009.

Romański M., Afery i nadużycia gospodarcze. Przyczynek do badań nad przestępczościa w PRL, „Studia z Historii Społeczno-Gospodarczej” 12, 2013.

Sawicki J., Charakterystyka sankcji w prawie karnym skarbowym, [w:] Współczesne przeksztatcenia sankcji karnych - zagadnienia teorii, wykładni i praktyki stosowania, red. P. Góralski, A. Muszyńska, Warszawa 2018.

Sawicki J., Wadliwe prowadzenie kantoru jako przestępstwo lub wykroczenie skarbowe, „Prokuratura i Prawo" 2009, nr 3.

Sienkiewicz Z., [w:] Prawo karne materialne. Część ogólna i szczególna, red. M. Bojarski, J. Giezek, Z. Sienkiewicz, Warszawa 2020.

Siwik Z., Systematyczny komentarz do ustawy karnej skarbowej. Część ogólna, Wrocław 1993.

Świda W., Prawo karne, Warszawa 1989.

Wilk L., [w:] L. Wilk, J. Zagrodnik, Kodeks karny skarbowy. Komentarz, Warszawa 2021.

Wójtowicz W., Prawo dewizowe z komentarzem, Warszawa 1992. 